\title{
Comparative Nitrogen Fixation, Native Arbuscular Mycorrhiza Formation and biomass Production Potentials of Some Grain Legume Species Grown in the Field in the Guinea Savanna Zone of Ghana
}

\author{
B. D. K. Ahiabor*, M. Fosu, I. Tibo and I. Sumaila \\ CSIR-Savanna Agricultural Research Institute, P. O. Box 52, Tamale, Ghana \\ *Corresponding author
}

\begin{abstract}
An on-station trial was conducted in the experimental field of Savanna Agricultural Research Institute at Nyankpala in the Northern Region of Ghana to assess the nitrogen fixation, native arbuscular mycorrhizal formation and biomass production potentials of cowpea (Vigna unguiculata), devil-bean (Crotalaria retusa), Mucuna pruriens var. utilis (black and white types) and Canavalia ensiformis with maize (Dorke SR) as the reference crop using the total nitrogen difference (TND) method. Plants were fertilized with $40 \mathrm{~kg} \mathrm{P} / \mathrm{ha}$ and $30 \mathrm{~kg} \mathrm{~K} / \mathrm{ha}$ at 2 weeks after planting and grown for 55 days after which they were harvested. The harvested biomass (separated into roots, stems and leaves) of each crop was oven-dried at $70{ }^{\circ} \mathrm{C}$ for $48 \mathrm{~h}$ to a constant weight. Cowpea and devil-bean produced approximately 5 and 6 t/ha biomass whereas Mucuna and Canavalia yielded about 2 t/ha biomass each. Although cowpea had the least number of arbuscular mycorrhiza fungal (AMF) spores in its rhizosphere, its roots were the most heavily colonized (34\%) and M. pruriens recording below 5\% colonization. Apart from C. ensiformis, the test legumes derived over 50\% of their total accumulated $\mathrm{N}$ from the atmosphere with cowpea being the most efficient (90\% Ndfa). Both $\mathrm{N}$ and $\mathrm{P}$ accumulations were significantly higher in cowpea than the other legumes due to increased $\mathrm{N}$ concentration and dry matter accumulation, respectively. In all the legumes, there was a direct positive correlation between the extent of mycorrhiza formation, biological $\mathrm{N}$ fixation and total $\mathrm{N}$ uptake. It could, therefore, be concluded that the extensive mycorrhiza formation in cowpea and its high $\mathrm{N}_{2}$-fixing potential resulted in a high shoot $\mathrm{N}$ and $\mathrm{P}$ uptake leading to a comparatively better growth enhancement. Cowpea could, therefore, be the grain legume for consideration in the selection of a suitable legume pre-crop to cereals for the amelioration of the low fertility of the degraded soils of the Guinea savanna zone of Ghana, and also as a source of food to fill the hunger gap that precedes the growing season in the Northern Region of Ghana.
\end{abstract}

\section{Introduction}

Northern Ghana ranks highest in the production of cereals and grain legumes in Ghana (PPMED, 1991). However, low soil fertility adversely affects the production of most cereals. Nitrogen (N) is the most limiting nutrient and its supply with phosphorus $(\mathrm{P})$ is essential for increased production of most cereals (Fugger, 1999). Lal (1989) indicated that the available N declines rapidly once cropping is commenced. He found that available soil $\mathrm{N}$ declined from $0.2 \%(0.5 \mathrm{~cm}$ depth) to $0.04 \%$ after 4 years of maize cropping without Leucaena leucocephala hedgerows. Van Keulen \& Van Heemst (1982) reported that moist savanna soils must supply $15 \mathrm{~kg} \mathrm{~N} / \mathrm{ha}$ and $2 \mathrm{~kg}$ $\mathrm{P} / \mathrm{ha}$ for each ton of maize grain produced. As a result, cereal yields without fertilization or soil amendment are very disappointing, ranging between $200-800 \mathrm{~kg} / \mathrm{ha}$.

Mineral fertilizers which are required to raise crop production levels are too expensive and most smallholder farmers cannot afford them. Intercropping or rotation of cereals with grain legumes ( due to their $\mathrm{N}_{2}$-fixing abilities) and crop residue management have been recommended as alternatives to improve cereal yields on these soils. The $\mathrm{N}_{2}$-fixing abilities of legumes can be enhanced not only by Rhizobium spp. but also by colonization of their roots by arbuscular mycorrhiza fungi (Asimi et al., 1980; Bayne \& Bethlenfalvay, 1987) which are present in the Guinea Savanna soils (Ahiabor, unpublished work). Unfortunately, the full potentials of these management practices on cereal yield improvement are not achieved since the grain legumes mobilize most of their fixed $\mathrm{N}$ into the grain which is exported when the grain is harvested. This 
decline in soil fertility is/worsened if the crop residues are not returned into the soil since for most of the degraded soils in the Guinea Savanna zone the only real means of restoration is to increase their organic matter content in a mulch-based system. The most efficient way of improving the $\mathrm{N}$ content of these soils is to grow legume crops sole in a rotation system and retain their residue in the field against the following cropping season.

Fosu et al. (2004) observed that Crotalaria retusa gave an average dry matter yield of $15 \mathrm{t} / \mathrm{ha}$ and a corresponding total $\mathrm{N}$ and $\mathrm{P}$ accumulations of $306 \mathrm{~kg} / \mathrm{ha}$ and $50 \mathrm{~kg} / \mathrm{ha}$, respectively, across locations in the Tolon-Kumbungu District. The work also indicated that $C$. retusa could fix about $112 \mathrm{~kg} / \mathrm{ha}$ of atmospheric $\mathrm{N}$ during the growing season and M. pruriens var. utilis also produced 9 $\mathrm{t} / \mathrm{ha}$ of dry matter with a corresponding total nitrogen of $180 \mathrm{~kg} / \mathrm{ha}$ per season. Since the overall amount of $\mathrm{N}$ supplied and the amount of organic matter (residue) generated by legumes depend, to a great extent, on the efficiency of the synergistic symbiotic processes of $\mathrm{N}_{2}$ - fixation and arbuscular mycorrhiza formation (AMF), this study compared the $\mathrm{N}_{2}$-fixation, AMF and biomass production potentials of five leguminous crops in the experimental field of the Savanna Agricultural Research Institute at Nyankpala.

\section{Trial location}

\section{Materials and methods}

The experiment was conducted on-station in the experimental field of the CSIR-Savanna Agricultural Research Institute (SARI) situated at Nyankpala $\left(9^{\circ} 25^{\prime \prime} \mathrm{N}\right.$ and $\left.0^{\circ} 58^{\prime \prime} \mathrm{W}\right)$ in the TolonKumbungu District of the Northern Region of Ghana. The Region experiences a monomodal rainfall pattern (April-October) with a mean annual rainfall of about $1000 \mathrm{~mm}$ and a variability of between 15-20\% (Kasei, 1988). The mean annual temperature is about $28{ }^{\circ} \mathrm{C}$ with the daily maximum sometimes being around $42{ }^{\circ} \mathrm{C}$ during the hottest months of February-March. Lowest temperatures (about $20{ }^{\circ} \mathrm{C}$ ) are recorded in December and January when the area comes under the influence of the dry and cold North-Easterly Trade winds (Harmattan winds) from the Sahara Desert. Relative humidity values are between $40-50 \%$ but may be as low as $9 \%$ during the afternoon in the driest months of November-March (Walker, 1962). Some chemical and physical properties of the soil (0-20 cm depth) of the experimental site are indicated in Table 1 which shows a very low available $\mathrm{N}(0.13 \%)$.

TABLE 1

Some chemical and physical properties of the soil of the trial plot

$\begin{array}{ll}\text { Property } & \text { Value } \\ \text { Chemical } & \\ \text { pH }\left(0.01 \mathrm{CaCl}_{2}\right) & \\ \text { Organic carbon }(\%) & 5.07 \\ \text { Nitrogen }(\%) & 1.59 \\ \text { Available P }(\mathrm{mg} / \mathrm{kg}) & 0.13 \\ \text { Exchangeable K }(\mathrm{mg} / \mathrm{kg}) & 8.4 \\ \mathrm{Ca}(\mathrm{mg} / \mathrm{kg}) & 88.42 \\ \mathrm{Mg}(\mathrm{mg} / \mathrm{kg}) & 301.39 \\ \left.\mathrm{CEC}(\mathrm{Cmol})^{(+)} / \mathrm{kg}\right) & 71.77 \\ \text { Base saturation }(\%) & 5.02 \\ \text { Total P }(\mathrm{mg} / \mathrm{kg}) & 46.2 \\ \text { Physical } & 37 \\ \text { Clay }(\%) & \\ \text { Sand }(\%) & 4.7 \\ \text { Silt }(\%) & 67.1 \\ & 28.2\end{array}$

Legume test plants 
Six legume species, cowpea (Vigna unguiculata), devil-bean (Crotalaria retusa), black and white varieties of Mucuna (Mucuna pruriens var. utilis) and Canavalia ensiformis, were tested for $\mathrm{N}_{2}$-fixation using maize (Dorke SR) (Zea mays) as a reference crop. Their ability to form arbuscular mycorrhiza with the native AM fungi was also assessed. These crops were planted on $6 \mathrm{~m} \times 4 \mathrm{~m}$ plots at four replications using a completely randomized design during the growing season of 2002. Cowpea (Bengpla) was sown at three seeds/hill at a spacing of $60 \mathrm{~cm} \times 20 \mathrm{~cm}$ but was thinned to two plants per hill 2 weeks after planting whereas the two varieties of M. pruriens and $C$. ensiformis were grown at two seeds/hill but thinned to one plant per hill at a planting distance of $70 \mathrm{~cm} \times 50 \mathrm{~cm}$. Devil-bean was drilled in rows $40 \mathrm{~cm}$ apart at the seed rate of 40 $\mathrm{kg} / \mathrm{ha}$ whilst the reference crop (maize) was maintained at one plant per hill at a planting distance of $75 \mathrm{~cm} \times 40 \mathrm{~cm}$. The test plants were fertilized with $40 \mathrm{~kg}$ P/ha (as triple superphosphate) and $30 \mathrm{~kg} \mathrm{~K} / \mathrm{ha}$ (as muriate of potash) at 2 weeks after planting.

\section{Plant sampling}

At 55 days after planting (DAP), all the crops were sampled for analysis. The dry matter yields of $M$. pruriens were determined within a $1 \mathrm{~m} \times 1 \mathrm{~m}$ wooden quadrat per plot and that of devilbean within a $0.5 \mathrm{~m} \times 0.5 \mathrm{~m}$ quadrat. Three plants each of maize, $C$. ensiformis and cowpea were harvested from the three inner rows per plot by cutting the above-ground part at the soil surface. The roots were carefully dug out of the soil and washed free of soil and organic particles on a 2$\mathrm{mm}$ mesh sieve under tap water. The harvested biomass (separated into roots, stems and leaves) of all the test crops was dried to a constant weight in a forced-air oven at $70{ }^{\circ} \mathrm{C}$ for $48 \mathrm{~h}$ and their dry weights recorded.

\section{Mycorrhizal analysis}

AM fungal spore count. At harvest, the rhizosphere soil from each test plant was collected and air-dried on pieces of used newspaper for a few days, sieved through a 2-mm mesh sieve and then thoroughly homogenized by stirring. Sufficient tap water was added to 5-g samples of the air-dry soil in a beaker and stirred vigorously with a glass rod for 2 min to dislodge the spores from the soil particles or organic debris. The soil suspension was leached through a $0.053-\mathrm{mm}$ mesh sieve to trap the spores on the sieve. The spores were retrieved by sucrose [60\% (w/v) sucrose solution] density-gradient centrifugation (modified from Daniels \& Skipper, 1984), and counted in a film of water under a stereomicroscope.

Estimation of AM fungal colonization. Prior to oven-drying, about $2 \mathrm{~g}$ of the fresh root samples with segments less than $2 \mathrm{~mm}$ in diameter were cut into approximately $2 \mathrm{~cm}$ pieces, mixed thoroughly and immediately fixed in $50 \%$ alcohol in $50 \mathrm{ml}$ extraction vinyl bottles and stored at room temperature in the laboratory. These fixed root samples were later washed free of the alcohol with tap water and transferred into petri dish and cleared with $100 \mathrm{gl}^{-1} \mathrm{KOH}$ solution in an oven at $90{ }^{\circ} \mathrm{C}$ for about 30 min and left to cool and washed in many changes of tap water from a wash bottle. Staining of the roots was done with $0.3 \mathrm{gl}^{-1}$ Chlorazol Black E (CBE) in lactoglycerol (1:1:1) lactic acid, glycerol and water) at $90{ }^{\circ} \mathrm{C}$ for $20 \mathrm{~min}$ in an oven (modified from Kormanik $\&$ McGraw, 1984). The degree of colonization of roots by arbuscular mycorrhiza fungi was estimated by visual observation (under a stereomicroscope) of the stained root segments mounted in 50\% (v/v) lactoglycerol by the grid-line intercept method (Giovanetti \& Mosse, 1980).

\section{Nutrient analysis}

Dried plant parts (roots, stems/vines/stalks and leaves) were ground using a mechanical grinder and the concentration of available phosphorus was determined by the Ammonium-molybdenum blue method (Murphy \& Riley, 1962; Watanabe \& Olsen, 1965). Total nitrogen was determined by the Kjeldahl method. 


\section{Nitrogen fixation measurement}

The proportion and amounts of fixed $\mathrm{N}_{2}$ in the different legume species was determined using the total $\mathrm{N}$ difference method with maize as a non-nitrogen-fixing reference crop.

\section{Statistical analysis}

The data were subjected to analysis of variance using Statistix software and significance of treatment effects were tested at 5\% level of probability. Means (of three replicates) were separated using the Least Significance Difference (LSD).

\section{Total dry matter production}

\section{Results}

Whereas devil-bean and cowpea produced approximately $5 \mathrm{t} / \mathrm{ha}$ and $6 \mathrm{t} / \mathrm{ha}$ biomass, respectively, M. pruriens (white), M. pruriens (black) and C. ensiformis produced biomass to the tune of around $2 \mathrm{t} /$ ha (Table 2).

TABLE 2

AMF colonization rates (\%), AMF spore populations (no./50 g a.d.s**) and dry weights ( $\mathrm{kg} / \mathrm{ha}$ ) of maize and four legume species grown on-station at Nyankpala in the Guinea Savanna zone of Ghana.

$\begin{array}{llll}\begin{array}{l}\text { Crop type } \\ \text { AMF colonization }\end{array} & \begin{array}{l}\text { AMF spore } \\ \text { rate }\end{array} & \begin{array}{l}\text { Dry weight } \\ \text { population }\end{array} \\ \text { Maize } & 32.5 \mathrm{a}^{*} & 173 \mathrm{bc} & 2694.4 \mathrm{~b} \\ \text { Devil-bean } & 10.8 \mathrm{~b} & 243 \mathrm{a} & 4876.0 \mathrm{a} \\ \text { Mucuna (white) } & 4.7 \mathrm{~b} & 209 \mathrm{ab} & 2122.7 \mathrm{~b} \\ \text { Mucuna (black) } & 4.3 \mathrm{~b} & 173 \mathrm{bc} & 2396.7 \mathrm{~b} \\ \text { Canavalia } & 9.7 \mathrm{~b} & 142 \mathrm{~cd} & 2382.2 \mathrm{~b} \\ \text { Cowpea } & 34.3 \mathrm{a} & 110 \mathrm{c} & 6232.6 \mathrm{a}\end{array}$

*In a column, values (means of three replicates) with similar letter(s) are not significantly different at $P=0.05$ separated using the least significance difference (LSD). **a.d.s = air-dried soil.

\section{$N_{2}$ fixation}

The amount of total $\mathrm{N}$ fixed by the legumes ranged between $23 \mathrm{~kg} / \mathrm{ha}$ for $C$. ensiformis and $145 \mathrm{~kg} / \mathrm{ha}$ for cowpea (Fig. 1). Apart from C. ensiformis, all the legumes derived over $50 \%$ of their accumulated $\mathrm{N}$ from the atmosphere with cowpea nodules being the most efficient in fixing atmospheric $\mathrm{N}$ which made up almost $90 \%$ of its total fixed N (Fig. 2). 


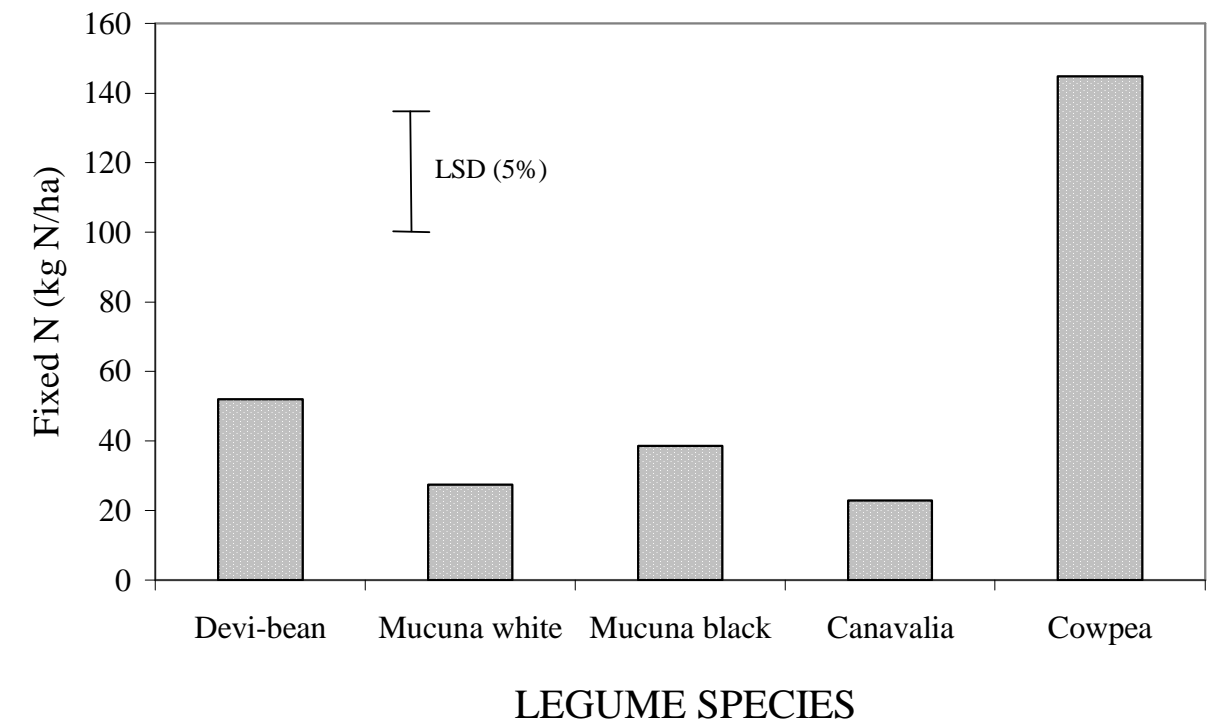

Fig. 1. Amounts of nitrogen fixed by four different legume species grown on-station at Nyankpala in the Guinea Savanna zone of Ghana

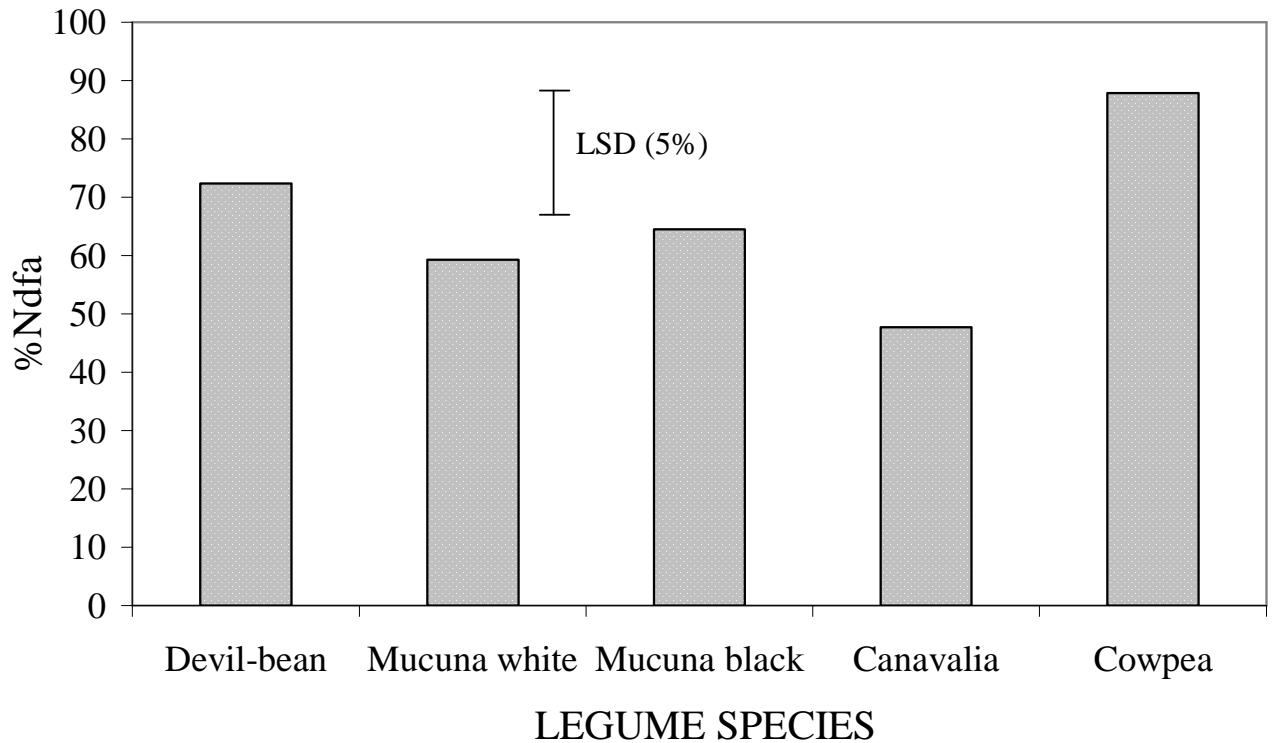

Fig. 2. Percent $\mathrm{N}$ derived from the atmosphere by four legume species grown on-station at Nyankpala in the Guinea Savanna zone of Ghana

\section{Nutrient $(N \& P)$ concentrations}

Cowpea tended to have a higher concentration of $\mathrm{N}$ in its shoot than the other legumes (Table 3 ). Concentration of $\mathrm{P}$ in the legumes was virtually constant in the roots and leaves whereas slight variations were observed in the stems/vines with the highest tendency observed in cowpea.

TABLE 3

$N$ and $P$ concentrations (\%) in the roots, stems and leaves of four legume 
species and maize grown on-station at Nyankpala in the Guinea Savanna zone of Ghana

\begin{tabular}{|c|c|c|c|c|c|c|}
\hline \multirow[b]{2}{*}{ Crop type } & \multicolumn{2}{|c|}{ Roots } & \multirow[t]{2}{*}{ Stem } & \multicolumn{3}{|c|}{ Leaves } \\
\hline & $\begin{array}{l}N \text { conc. } \\
P \text { conc. }\end{array}$ & P conc. & & $N$ conc. & P conc. & $N$ \\
\hline Maize & $1.19 b^{*}$ & $0.03 \mathrm{~b}$ & $0.59 \mathrm{c}$ & $0.14 \mathrm{ab}$ & $0.80 \mathrm{~b}$ & $0.17 \mathrm{a}$ \\
\hline Devil-bean & $1.24 \mathrm{~b}$ & $0.15 \mathrm{a}$ & $2.34 \mathrm{ab}$ & $0.15 \mathrm{ab}$ & $1.42 \mathrm{ab}$ & $0.17 \mathrm{a}$ \\
\hline Mucuna (white) & $2.74 \mathrm{a}$ & $0.18 \mathrm{a}$ & $1.82 \mathrm{abc}$ & $0.12 \mathrm{~b}$ & $1.91 \mathrm{ab}$ & $0.20 \mathrm{a}$ \\
\hline Mucuna (black) & $2.23 \mathrm{ab}$ & $0.18 \mathrm{a}$ & $2.53 \mathrm{ab}$ & $0.17 \mathrm{ab}$ & $1.40 \mathrm{~b}$ & $0.21 \mathrm{a}$ \\
\hline Canavalia & $1.59 \mathrm{ab}$ & $0.20 \mathrm{a}$ & $1.12 \mathrm{bc}$ & $0.18 \mathrm{ab}$ & $1.66 \mathrm{ab}$ & $0.15 \mathrm{a}$ \\
\hline Cowpea & $1.85 \mathrm{ab}$ & $0.15 \mathrm{a}$ & $3.10 \mathrm{a}$ & $0.26 \mathrm{a}$ & $2.75 \mathrm{a}$ & $0.23 \mathrm{a}$ \\
\hline
\end{tabular}

* In a column, values (means of three replicates) with similar letter(s) are not significantly different at $P=0.05$ separated using the least significance difference (LSD).

\section{Total $N \& P$ uptake}

The cereal reference crop accumulated the lowest amount of nitrogen but this was suprisingly statistically comparable to those of $M$. pruriens (white) and C. ensiformis (Fig. 3). N accumulation in cowpea was particularly high - at least about $135 \%$ more than each of the other legumes. Phosphorus accumulation was significantly high in cowpea compared to the rest of the test crops in which this parameter generally remained constant (Fig. 4). A relatively high proportion of the $\mathrm{P}$ in cowpea was distributed in its stem (Fig. 5).

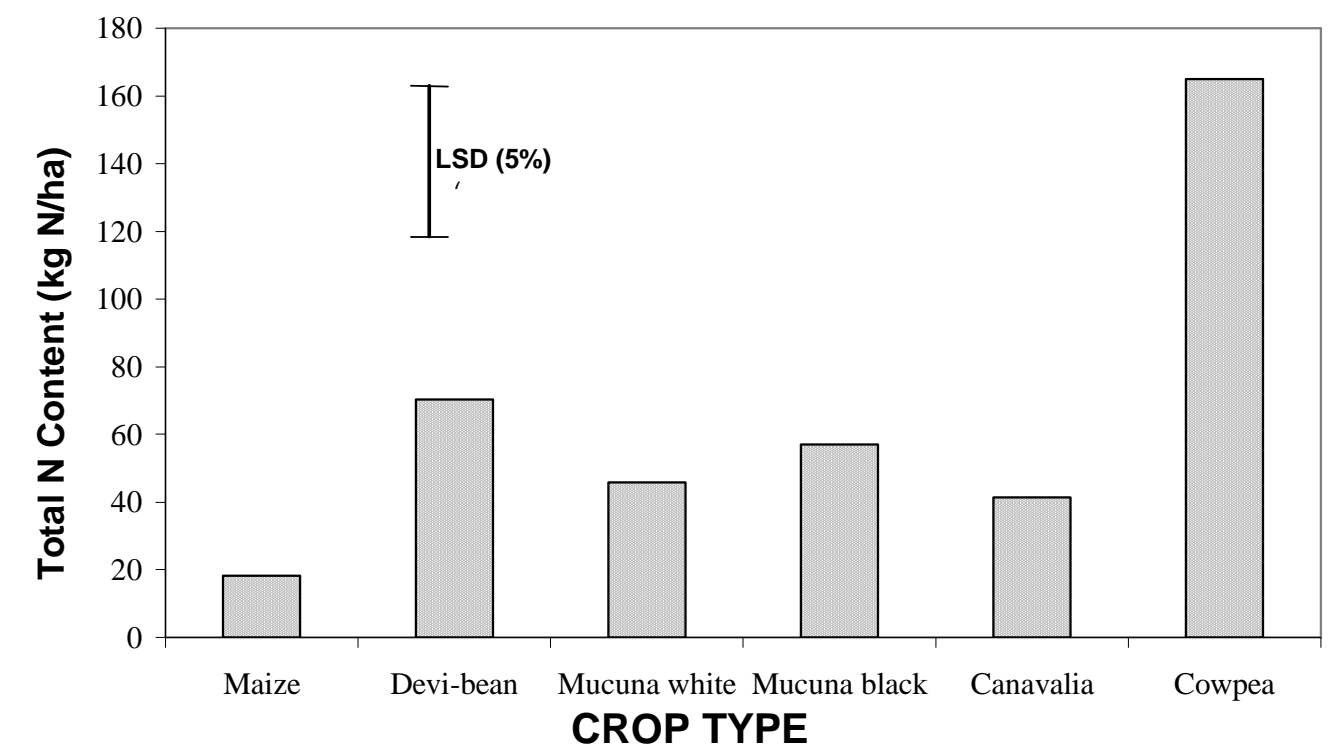

Fig. 3. Total nitrogen uptake in maize and four legume species grown on-station at Nyankpala in the Guinea Savanna zone of Ghana 


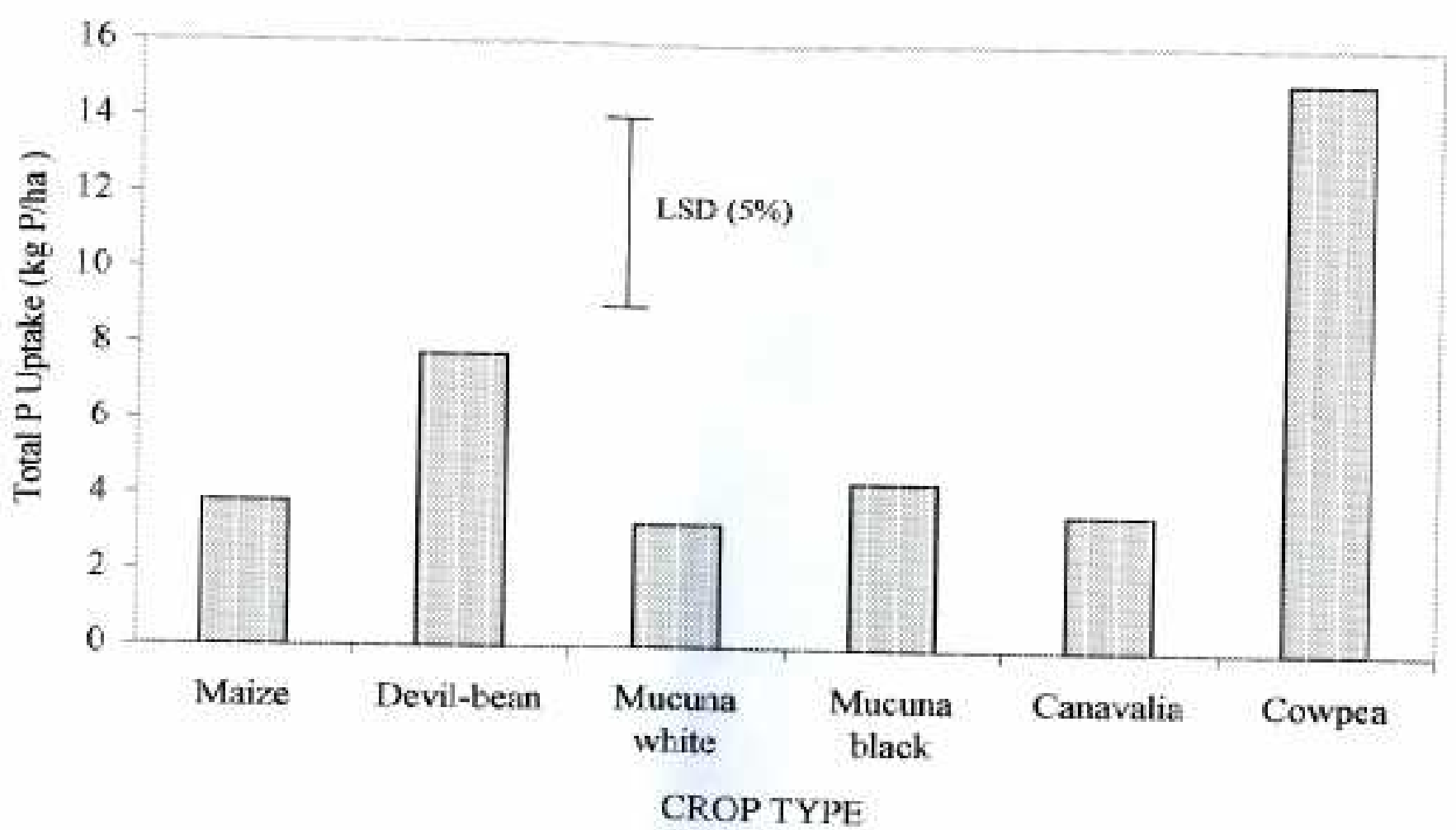

Fig. 4. Total phosphorus uptake in maize and four legume species grown on-station at Nyankpala in the Guinea Savanna zone of Ghana

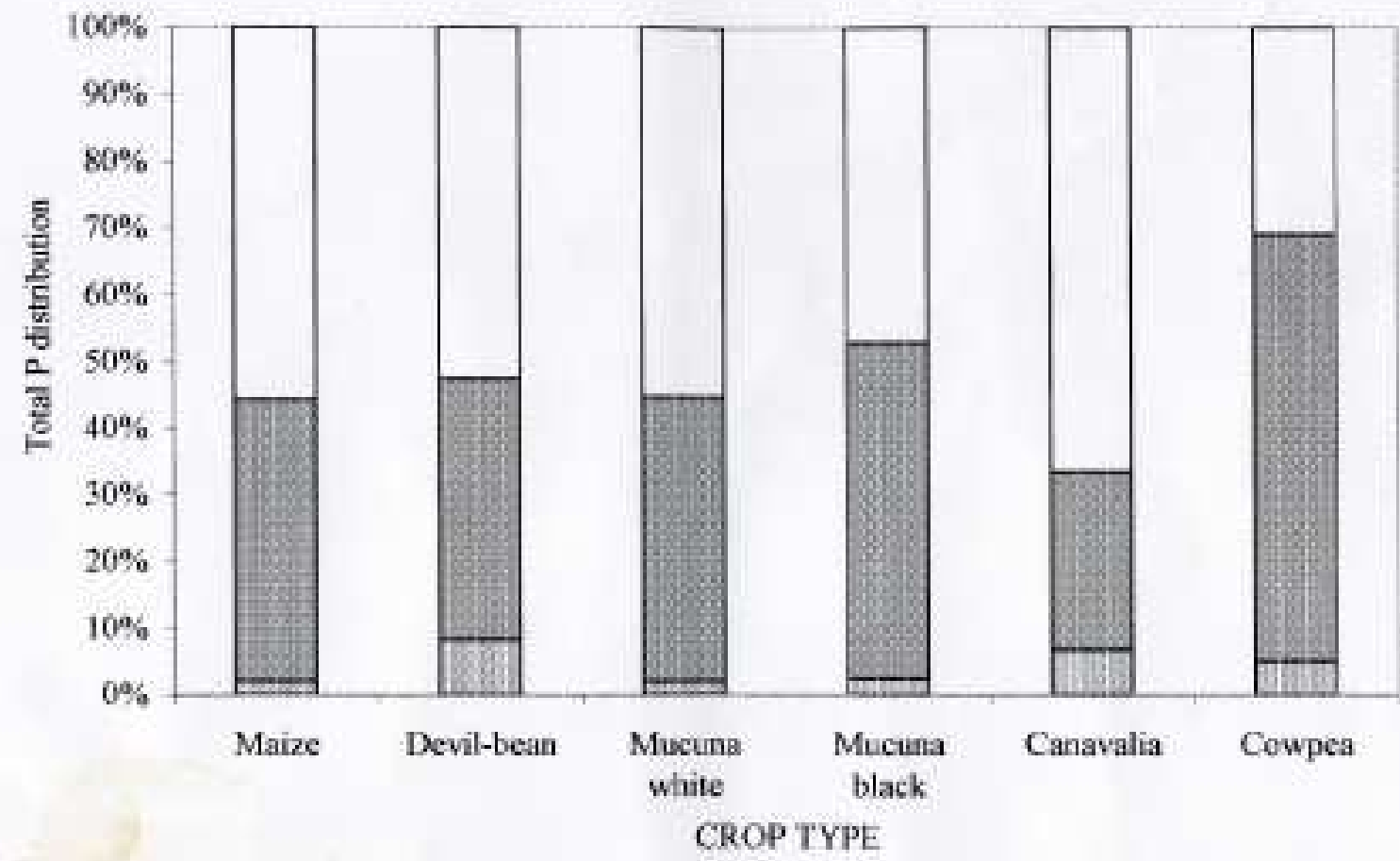

Fig. 5. Distribution of total phosphorus content in parts of maize and four legume species grown on-station at Nyankpala in the Guinea Savanna zone of Ghana 


\section{Colonization by native AMF AM fungi}

Cowpea roots were the most heavily colonized with the Mucuna plants recording as low as less than $5 \%$ degree of mycorrhiza colonization. The reference cereal crop had a comparable colonization rate as that of cowpea (Table 2). Mycorrhizal fungal spore population in the rhizosphere of the legumes was not commensurate with the colonization rates (Table 2). The highest colonized crop (cowpea) generally had the least spore population in its rhizosphere. Devil-bean, which had a significantly lower degree of AMF colonization of its roots than cowpea and maize, supported a remarkably higher AMF spore population in its immediate root zone than the two crops (Table 2).

\section{Discussion}

The study has shown that, apart from cowpea, the other test legumes fixed equal amounts of nitrogen and were also colonized to comparable degrees when grown without artificial microbial inoculations. There is a direct positive correlation between extent of mycorrhiza formation, biological nitrogen fixation and total nitrogen accumulated in shoots (Table 4). This is strengthened by the observation that cowpea, which had the most extensive mycorrhiza colonization, fixed the highest amount of atmospheric nitrogen resulting in a high shoot $\mathrm{N}$ leading to a comparatively better growth enhancement. This observation in cowpea could be explained by the conclusions of Ames et al. (1983) and Barea et al. (1987) who used ${ }^{15} \mathrm{~N}$ techniques to show that both $\mathrm{NH}_{4}^{+}{ }^{+} \mathrm{N}$ and $\mathrm{NO}_{3}-\mathrm{N}$ can readily be absorbed by extra-radical vesicular-arbuscular mycor-rhizal (VAM) hyphae, and that growth enhance-ment of legumes by VAM can be attributed both to enhanced $\mathrm{N}_{2}$ fixation as well as improved $\mathrm{N}$ uptake from soil, especially the $\mathrm{NH}_{4}^{+}-\mathrm{N}$.

TABLE 4

Correlation (Pearson) coefficients of AMF colonization, fixed $N$ and total plant $N$ uptake

$\begin{array}{cc}\text { AMF } & \text { Fixed } \\ \text { Colonization } & \text { nitrogen }\end{array}$

$\begin{array}{lll}\text { Fixed N } & 0.7865 & \\ P \text {-value } & 0.0005 & \\ & & \\ \text { Total N uptake } & 0.7827 & 0.9994 \\ P \text {-value } & 0.0006 & 0\end{array}$

Asimi et al. (1980) also indicated that stimulation of nodule activity in soybean grown at different soil P levels might be due to direct and preferential enhancement of nodule formation by vesicular-arbuscular mycorrhizal (VAM) fungi. Since cowpea had the highest AMF colonization than all the other legumes, the associated extensive AMF hyphal system may have facilitated the absorption of any ammonium that might have been released from nodules through their (AMF hyphae) production of glutamine synthetase, thereby, improving the $\mathrm{N}$ economy of the cowpea plant (Smith et al., 1985). The usual dilution of $\mathrm{N}$ in plant shoots associated with increased shoot biomass (Ahiabor \& Hirata, 1994) was not observed in cowpea in this study as its $N$ concentration remained comparatively high, especially in the leaves and stems. The widely reported enhance-ment of $\mathrm{P}$ nutrition in mycorrhizal plants (Smith \& Read, 1997) was not observed in the highly mycorrhizal cowpea since both its root and shoot $\mathrm{P}$ concentration levels are not significantly different from the other poorly colonized legume species.

The total $\mathrm{P}$ accumulation in cowpea was, however, significantly high compared to the other test crops with a sizeable portion of it being partitioned in its stems. This supports the commonly 
held view that the improved shoot $\mathrm{P}$ uptake associated with mycorrhizal plants is largely the result of enhanced shoot growth of such mycorrhizal plants (Daft \& El-Giahmi, 1974; Mosse et al., 1976; Atayese et al., 1993) as observed in cowpea in this study. In a study to investigate the response of three mycohhrizal legume species (cowpea, pigeonpea and groundnut) to the combined application of rock phosphate and a soluble phosphate, Ahiabor \& Hirata (2003) observed that cowpea was the most responsive in terms of shoot growth and shoot $\mathrm{P}$ uptake but concluded that the positive shoot growth response of cowpea was not due to a favourable $\mathrm{P}$ nutrition but might have been the result of the effects of a greater mycorrhizal activity and an enhanced root growth on some unmeasured factor(s).

It could be concluded from the results of the study that cowpea would be the best candidate among the four legume species tested in the selection of a suitable legume pre-crop for the amelioration of the inherent low fertility of the degraded soils of the Guinea Savanna zone of northern Ghana, especially for increased productivity and production of cereals in this agroecological zone. This could be possible if all or most of the $\mathrm{N}$ fixed by the plant could remain in the soil and not be lost and also if the plant organic residue could be managed well to protect it from the hazards of the annual bushfires (which are a menace in this agro-ecological zone) so that its nutrients could be accessed by the succeeding cereal crop. However, cowpea is normally grown for its grain and it is known that a high proportion of $\mathrm{N}$ fixed goes into the grains and little is left in the stover. This not withstanding, it can be predicted, on the basis of Van Keulen \& Van Heemst's conclusion, that the cowpea biomass produced in this experiment could support the production of about $11 \mathrm{t} / \mathrm{ha}$ of maize grain in the following season in terms of its $\mathrm{N}$ content, assuming there is complete or adequate mineralization of the biomass without any losses.

In order to derive maximum benefit from the cowpea crop, therefore, a judicious management of its post-harvest residue should be ensured, say by protecting it against the incidence of bushfires and grazing by free-range animals, or by burying it soon after harvesting the grains. However, in situations where the incidence of bushfires remains a major threat to agriculture, devil-bean could be the alternative option due to its relatively high biomass production, $\mathrm{N}_{2}$ fixation, and $\mathrm{N}$ accumulation values obtained in this study, coupled with its perennial nature, its non-palatability to animals and high tolerance to drought and bushfires.

\section{Acknowledgement}

The authors are profoundly grateful to the Food Crops Development Project of the Ministry of Food and Agriculture, Ghana, for providing the funds for this research. They also sincerely thank the staff of the Soil Chemistry Laboratory of the CSIR-Savanna Agricultural Research Institute, Nyankpala, for analysing the plant samples used.

\section{References}

Ahiabor B. D. and Hirata H. (1994). Characteristic responses of three tropical legumes to the inoculation of two species of VAM fungi in Andosol soils with different fertilities. Mycorrhiza 5: 63-70.

Ahiabor B. D. and Hirata H. (2003). Associative influence of soluble phosphate, rock phosphate and arbuscular mycorrhizal fungus on plant growth and phosphorus uptake of three tropical legumes. W. Afr. J. appl. Ecol. 4: 7590 .

Ames R. N., Reid C. P. P., Porter L. K. and Cambardella C. (1983). Hyphal uptake and transport of nitrogen from two ${ }^{15} \mathrm{~N}$-labelled sources of Glomus mosseae, a vesicular-arbuscular mycorrhizal fungus. New Phytol. 95: 381-396.

Asimi S., Gianinazzi-Pearson V. and Gianinazzi S. (1980). Influence of increasing soil phosphorus levels on interactions between VA mycorrhizae and Rhizobium in soybeans. Can. J. Bot. 58: 2200-2205.

Atayese M. O., Awotoye O. O., Osonubi O. and Mulongoy K. (1993). Comparisons of the influence of vesiculararbuscular mycorrhiza on the productivity of hedgerow woody legumes and cassava at the top and base of a hillslope under alley cropping systems. Biol. Fert. Soils. 16: 198-204.

Barea J. M., Azcon-Aguilar C. and Azcon R. (1987). Vesicular-arbuscular mycorrhiza improve both symbiotic $\mathrm{N}_{2}$ fixation and $\mathrm{N}$ uptake from soil as assessed with a ${ }^{15} \mathrm{~N}$ technique under field conditions. New Phytol. 106: 717-725. 
Bayne H. G. and Bethlenfalvay G. J. (1987). The Glycine-Glomus-Rhizobium symbiosis. IV. Interactions between mycorrhizal and nitrogen-fixing Endophytes. Pl. Cell Envir. 10: 607-617.

Daft M. J. and El-Giahmi A. A. (1974). Effect of endogone mycorrhiza on plant growth. VIII. Influence of infection on the growth and nodulation in French bean (P. Vulgaris). New Phytol. 73: 1139-1147.

Daniels B. A. and Skipper H. D. (1984). Methods of recovery and quantitative estimation of propagules from soil. In Methods and Principles of Mycorrhizal Research. (N. C. Schenck, ed.), pp. 29-35. The American Phytopathological Society, St. Paul, Minnesota, USA.

Fosu M., Kühne R. F. and Vlek P. L. G. (2004). Improving maize yield in the Guinea Savannah zone of Ghana with leguminous cover crops and PK fertilization. J. Agron. 3(2): 115-121.

Fugger W-D. (1999). Evaluation of potential indicators for soil quality in savanna soils in northern Ghana, (West Africa). (PhD Thesis.) Georg-August-Universität, Göttingen, Germany.

Giovanetti M. and Mosse B. (1980). An evaluation of techniques for measuring vesicular-arbuscular mycorrhizal infection in roots. New Phytol. 84: 489-500.

Kasei C. N. (1988). The physical environment of semi-arid Ghana. In Challenges in Dryland Agriculture. A Global Perspective. Proc. Intern. Conf. On Dryland Farming. (P. W. Unger, T. V. Sneed, W.R. Jordan and R. Jensen, ed.), pp. 350-354. Amarillo/Bushland, Texas, USA.

Kormanik P. P. and McGraw A. C. (1984). Quantification of vesicular-arbuscular mycorrhizae in plant root. In Methods and Principles of Mycorrhizal Research. (N. C. Schenck, ed.), pp. 37-45. The American Phytopathological Society. St. Paul, MN.

Lal R. (1989). Agroforestry systems and soil surface management of a tropical alfisol. Agrofor. Syst. 8: 7-29.

Mosse B., Powell C. L. I. and Hayman D. S. (1976). Plant growth responses to vesicular-arbuscular mycorrhiza. IX. Interactions between VA mycorrhiza, rock phosphate and symbiotic nitrogen fixation. New Phytol. 76: 331-342.

Murphy J. and Riley J. P. (1962). A modified single solution method for the determination of phosphate in natural waters. Anal. Chem. Acta. 27: 31-36.

PPMED (Policy Planning, Monitoring and Evaluation Department) (1991). Agric. Bull. Ministry of Food and Agriculture, Accra, Ghana.

Smith S. E., St. John B. J., Smith F. A. and Nicholas D. J. D. (1985). Activity of glutamine synthetase and glutamate dehydrogenase in Trifolium subterraneum L. and Allium cepa L.: Effects of mycorrhizal infection and phosphate nutrition. New Phytol. 99: 11-227.

Smith S. E. and Read D. J. (1997). Mycorrhizal Symbiosis, 2nd edn. Academic Press, San Diego, Calif., USA.

Van Keulen H. and Van Heemst H. D. J. (1982). Crop response to the supply of macronutrients. Agric. Res. Rep. 916 (Versl Landbk Onderz), Pudoc, Wageningen, The Netherlands.

Walker H. O. (1962). Weather and climate. In Agriculture and Land-use in Ghana. (J. Wills, ed.). Oxford University Press, London.

Watanabe F. S. and Olsen S. R. (1965). Test of an ascorbic acid method for determining phosphorus in water and $\mathrm{NaHCO}_{3}$ extracts from soil. Soil Sci. Soc. Am. Proc. 29: 677-678. 